\title{
Philosophy of Disability as Critical Diversity Studies
}

\author{
Shelley L. Tremain \\ Independent Scholar
}

Shelley L. Tremain holds a PhD in philosophy, has taught in Canada, the United States, and Australia, and publishes on a range of topics, including philosophy of disability, Foucault, ableism in feminist philosophy, and genetic technologies. She is the author of Foucault and Feminist Philosophy of Disability (University of Michigan Press, 2017), which was awarded the 2016 Tobin Siebers Prize for Disability Studies in the Humanities, and editor of Foucault and the Government of Disability (University of Michigan Press, 2005; 2015). She was also the 2016 recipient of the Tanis Doe Award for Disability Study and Culture in Canada.

\begin{abstract}
Critical diversity studies (CDS) can be found within "traditional" or "established" university disciplines, such as philosophy, as well as in relatively newer departments of the university, such as African studies departments, women's and gender studies departments, and disability studies departments. In this article, therefore, I explain why philosophy of disability, an emerging subfield in the discipline of philosophy, should be recognized as an emerging area of CDS. My discussion in the article situates philosophy of disability in CDS by both distinguishing this new subfield's claims about disability from the arguments about disability that mainstream philosophers make and identifying the assumptions about social construction and antiessentialism that philosophy of disability shares with other areas of CDS. The discussion is designed to show that a (feminist) philosophy of disability that draws upon the work of Michel Foucault will transform how philosophers understand the situation of disabled people. By drawing upon Foucault, I offer philosophers of disability and other practitioners of CDS a new understanding of disability as an apparatus of power relations.
\end{abstract}

\section{KEYWORDS}

philosophy of disability, mainstream analytic political philosophy, John Rawls, disabled people's movements, feminist philosophy of disability, Michel Foucault, apparatus of disability 


\section{Philosophy of Disability in Critical Diversity Studies (CDS)}

When academics talk about "critical diversity studies" (hereafter referred to as CDS), it is generally assumed that they are referring to the relatively recent interdisciplinary fields of inquiry that are variously based on identity, social position, group membership, shared experience, and history: women's and gender studies, Africana studies, LGBTQI studies, and disability studies. Programs in some or all of these (and other) fields of CDS are now included in the curricula of most universities and colleges worldwide. Furthermore, many universities around the world have degree-conferring departments in at least some fields of CDS. In some institutions, one can major in fields of CDS, while in other places, one must combine one's work in, say, disability studies or critical race studies, with a more "traditional" or established discipline such as philosophy, where the latter-philosophyis regarded as one's major area of specialization (for which a degree is conferred), while the former-disability studies or critical race studies-is regarded as one's minor area of specialization (for which a diploma or certificate may be conferred).

Nevertheless, forms of CDS can increasingly be found within "traditional" disciplines themselves; that is, a growing number of university and college departments that house age-old, conventional disciplines offer courses that enable specialization in areas that are most aptly identified as varieties of CDS, areas of specialization that talk back to, or even against, the established disciplines within which they reside. Throughout the last decade especially, philosophy has, reluctantly, become one such discipline. For despite a great deal of conservative resistance and even hostility from certain corners of philosophy, a steadily growing number of philosophy departments offer courses in feminist philosophy, philosophy of race, queer theory, and other CDS areas. The subject matter of these courses is respectively designed to transform the discipline of philosophy by challenging the sexism, racism, Eurocentrism, homophobia, heterosexism, and transphobia of claims that mainstream philosophers make; critique the methods and "foundational" assumptions of Eurocentric, Western philosophy along these lines; and introduce new counter discourses and thinkers into the "canon" of philosophy. Indeed, some philosophy departments now deliberately utilize areas of CDS as institutional mechanisms and strategies to redress and eliminate the Eurocentrism, androcentrism, and whiteness of the discipline of academic philosophy, as well as to ameliorate the historical underrepresentation and exclusion of some social groups from the profession of academic philosophy.

In this article, I outline the parameters of one area of CDS in the discipline of philosophynamely, philosophy of disability—in part by distinguishing the claims of this emerging subfield of philosophy from the claims about disability made in more established, mainstream, and dominant areas of the discipline. Mainstream philosophy, like other "traditional" disciplines of the university, continues to operate under the guise of the values of neutrality, rationality, and objectivity. Yet, the discipline of philosophy, like every one of the disciplines that constitutes the modern university, implicitly promotes certain ontologies, methodologies, and epistemologies, that is, certain political, social, economic, cultural, and institutional mechanisms and influences condition philosophy and every other discipline of the modern university, despite the fact that conventional, established 
disciplines such as philosophy continue to be represented-and to variously represent themselves-as value neutral, detached, disinterested, and impartial. By contrast, philosophy of disability, like other areas of CDS, explicitly represents itself as politically motivated in character and socially engaged in content; like other areas of CDS, philosophy of disability has, more or less, grown out of and remains associated with a social and political movement. In what follows, I identify some of the central motivational assumptions of philosophy of disability, explain the extent to which these assumptions have roots in disabled people's movements, and highlight key interventions and contested categories in this new subfield of philosophy, this new addition to the roster of CDS.

\section{Situating Philosophy of Disability in Philosophy}

Most philosophers continue to hold the view that certain subfields of philosophy-metaphysics, ethics, logic, epistemology, and philosophy of language-are foundational to the discipline of philosophy, uniquely distinguishing philosophy from other disciplines of research and teaching and affirming its self-ascription as "the queen of the sciences." Philosophers who circumscribe the "foundations" of philosophy in this way maintain that these subfields of the discipline are the necessary, essential, and "core" elements of philosophy, while other subfields of philosophical inquiry-such as philosophy of race, feminist philosophy, and philosophy of disability-are (mere) applications and contingent derivatives of these fundamental subfields. Furthermore, philosophers who distinguish in this way between "core" subfields of philosophy and "applied" subfields of philosophy generally regard the questions and concerns that constitute the former subfields as timeless, disinterested, and universal in character and, conversely, take the questions and concerns that constitute the latter subfields to be accidental, interested, and partial (on this distinction, also see Shelby, 2007, p. 13). Against this understanding of the architecture of philosophy, my discussion in what follows assumes that every philosophical question, concern, and approach, as well as every subfield that these questions, concerns, and approaches constitute, is a value-laden artifact of historically contingent and culturally specific discourses.

My assertion about the historical contingency and cultural specificity of philosophical discourses encompasses philosophy of disability itself, as well as its discursive objects. Although many, if not most, philosophers of disability presuppose that the phenomena of disability are transhistorical and transcultural, identifying claims about disability and disabled people in the writings of Plato, Locke, and other philosophers in the distant past of Eurocentric, Western philosophy, I maintain that disability is a historically and culturally specific phenomenon rather than transhistorical and transcultural in character. In fact, I want to pinpoint the publication of John Rawls's A Theory of Justice in 1971 as a key fulcrum of the "problematization" of disability in contemporary philosophy and, hence, of the form that broad swaths of the discussion about disability currently take in philosophical discourse. Michel Foucault, in a review of the method that he employed in his studies of abnormality, madness, and criminality, introduced the notion of problematization, remarking that inquiry into the problematization of a given state of affairs tries to uncover how the different solutions to a "problem" have been constructed and how these different 
solutions resulted from the problematization of that contingent state of affairs in the first place (Foucault, 2003, pp. 20-24). My claim that Rawls's argument in A Theory of Justice largely precipitated the problematization of disability in contemporary philosophy is thus a claim about the distinct ways in which disability emerged as an urgent problem in philosophy, about how the problem of disability has been constructed in philosophy, and about how, within philosophical discourses, certain solutions to the problem of disability have come to be advanced.

I also want to pinpoint the publication of Rawls's text as an inadvertent catalyst for critical philosophical work on disability, although I predict that many philosophers and theorists of disability will (initially at least) object to my doing so. That is, I want to argue that the publication of Rawls's landmark book and subsequent discussion of it in mainstream political philosophy contributed significantly to the emergence of the counterdiscourse of philosophy of disability. In the aftermath of the publication of Rawls's book, mainstream philosophers have made a concerted endeavor to formulate and respond to questions about disability such as these: What, if anything, does society owe to disabled people? How should society compensate disabled people for their brute bad luck? Is it morally permissible to euthanize severely disabled people? Is it morally permissible to experiment on cognitively disabled people (see Tremain, 2017)? Nevertheless, more and more philosophers-some who write in direct response to the set of questions about disability that Rawls's text motivated in mainstream (analytic) political philosophy and others whose writing on disability stems from feminist and Foucauldian analyses of power, the body, normality, subjectivity, and identity-have contested or defied mainstream philosophical work on disability by articulating and responding to questions such as these: How do accepted philosophical understandings about (say) autonomy, rationality, subjectivity, and individuality fail to account for the circumstances of disabled people's lives? What are the most effective philosophical devices to show that disabled people make up a disenfranchised minority? What conceptual tools are required to show that disability is a social construction? Although most philosophers of disability assume that the subfield of philosophy of disability (as a form of CDS) ought to promote the latter sort of question rather than the former sort of question, the pivotal role that Rawls's $A$ Theory of Justice inadvertently played in both the way that the problematization of disability has come to be framed in philosophy and how philosophers of disability have responded to that problematization cannot be denied.

Let me point out, then, that the questions that mainstream philosophers have asked (and continue to ask) about disability largely rely upon a cluster of motivational assumptions that take for granted the metaphysical status and epistemological character of disability, casting it as a self-evident and hence philosophically uninteresting designation that science and medicine can accurately represent. On the terms of this cluster of assumptions, disability is a prediscursive, transcultural, and transhistorical disadvantage, an objective human defect, that is, a non-accidental, biological human property, attribute, or characteristic that ought to be prevented, corrected, eliminated, or cured. That these assumptions are contestable and that disability might be a historically and culturally specific and contingent social phenomenon, a complex apparatus of power rather than a 
natural attribute or property that certain people possess is not considered, let alone seriously entertained. My argument—an argument with which (most) analytic philosophers of disability disagree-is that disability is a historically and culturally contingent apparatus of force relations all the way down.

Although critical analysis of disability has made noticeable inroads elsewhere in the humanities and social sciences, such analysis of disability-as a politically informed variety of CDS-remains severely marginalized within philosophy, a state of affairs that should be attributed to a complex and complicated set of interrelated factors, including the historical composition and demographics of professional philosophy itself; the narrowing concentration of the prevailing subject matter and techniques of philosophy; the increasingly close association between philosophy and the sciences; and the otherwise limited theoretical, discursive, and political focus of much philosophy. Indeed, the assumption that disability is appropriately and adequately addressed in the domains of medicine, the life sciences, and related fields has, itself, shaped philosophy departments, influencing hiring practices and decisions as well as course curricula, conference lineups, the composition of professional networks and editorial boards, the contents of edited collections, and so on (see Tremain, 2017; also see Tremain, 2010, 2013, 2014). In short, the assumption that disability is a philosophically uninteresting human characteristic, on one hand, and the underrepresentation of disabled philosophers and continued marginalization of philosophy of disability are mutually constitutive and mutually reinforcing, entangled and entwined.

\section{Mainstream Philosophy as a Catalyst for Philosophy of Disability}

In A Theory of Justice, Rawls advanced a social contract theory in the terms of which members of a given society would, under conditions of uncertainty, choose two principles of justice that apply to the "basic structure of society." The first principle-the principle of liberty to which Rawls gave lexical priority-confers upon any given member of society equal right to the most extensive liberties compatible with the enjoyment of the most extensive liberties by all other members of society. The latter principle-one component of which Rawls dubbed "the difference principle"-holds that offices and positions must be open to all people under conditions of equal opportunity and that social inequalities are acceptable that work to the benefit of the most disadvantaged members of society. Under circumstances of justice (construed as conditions of scarcity), Rawls argued, these two principles would be recognized as mutually advantageous by "normal and cooperating citizens" to whom information about their respective social positions, personal characteristics, occupations, place of birth, sex, and so on is unavailable. Although Rawls argued that the counterfactual character of the conditions of uncertainty that his justice as fairness imposed was a heuristic device ("device of representation"), the nature and function of the device has been hotly debated: both lauded as intuitively appealing by proponents of Rawls's theory and ridiculed by opponents of the theory who charge that (among other things) such "ideal theory" obscures, and indeed fosters, social inequalities. Charles Mills (2005) has argued, for instance, that Rawls's famous distinction between 
ideal and nonideal theory is reductive and undermines, if not ignores, the knowledges that members of marginalized groups produce.

In "Equality of What?" philosopher and economist Amartya Sen (1979) claimed that Rawls misunderstood the requirements of justice and therefore chose the wrong "metric" by which to measure improvements in people's circumstances and hence the wrong basis for a theory of justice. For Sen, a theory of justice ought to be directed at what people can respectively "do" and "be," that is, ought to attend to their respective functionings and capabilities rather than revolve around the distribution (in some uniform, undifferentiated fashion) of opportunities and other goods. Sen argued, furthermore, that insofar as Rawls's theory of justice as fairness covered over differences between people-enabled by the Rawlsian distinction between "natural" disadvantages (deemed to be morally arbitrary) and "social" disadvantages (deemed to be morally relevant)-Rawls circumscribed the domain of justice too narrowly. In Sen's view, Rawls's justice as fairness, if implemented, would likely lead to dire consequences for the very people-including disabled people - that a theory of justice should most urgently assist because the Rawlsian distinction between natural and social disadvantages situates the concerns and requirements of these people outside the scope of justice, that is, in the realm of benevolence and good will or in the domain of health care, a domain that Rawls did not regard as integral to the basic structure of society. Although Sen recognized that a theory of justice must address distribution to disabled people, he nevertheless naturalized disability, ultimately locating the "problem" of disability in disabled people themselves, as Ronald Dworkin (1981a), among others, has noted.

In a set of two articles, respectively titled "What Is Equality? Part 1: Equality of Welfare" and "What Is Equality? Part 2: Equality of Resources," Dworkin (1981a, 1981b) offered additional responses to the "problem" of disability that Rawls, initially, and Sen, subsequently, identified. Whereas the former article encompassed Dworkin's criticism of both Rawls's justice as fairness and Sen's capability approach, the latter article advanced Dworkin's own argument that resources should be the metric (to use Sen's term) by which to measure improvements in social justice. Dworkin agreed with Sen that Rawls erred insofar as he deemed the possession or lack of "natural" characteristics, talents, and capacities to be morally arbitrary and thus not the appropriate subject matter of a theory of justice. Nevertheless, Dworkin disagreed with Sen about the appropriate way for a theory of justice to address (so-called) natural human variation. In fact, central to Dworkin's theory of equality of resources was a proposal formulated to incorporate what Rawls had removed from consideration in his theory of social justice. The proposal took the form of a hypothetical insurance market designed to "compensate for handicaps," that is, make cash payments to "handicapped" people based on their assessments and calculations of the opportunity costs that accrued to them due to their "handicaps." Dworkin believed that his hypothetical insurance scheme improves upon "welfarist" approaches to social justice for disabled people. In another context, I have argued, however, that the design of Dworkin's insurance market violates his own recommendations for equality because such an insurance market would compel disabled people to accept an argument that threatens to compromise, if not undermine, their self-respect (Tremain, 1996). I want to point out, 
furthermore, that insofar as mainstream political philosophers have generated the problematization of the apparatus of disability thus, that is, insofar as they have conceived the social inequalities that accrue to disabled people as the inevitable consequences of a selfevident physiological, or natural, human characteristic (property, difference, or attribute), they have presupposed certain assumptions about the relation between biology and society that philosophies of disability and my philosophy of disability in particular aim to undermine.

\section{Social Construction and Activist Origins of Philosophy of Disability}

In her 2016 Tanner Lectures, Dorothy E. Roberts astutely describes how asymmetrical relations of social power are naturalized in certain academic discourses, distinguishing heuristically between two approaches to the question of the relation between biology and society: "the old biosocial science" and "the new biosocial science." As Roberts explains it, the former approach posits that biological differences produce social inequality, whereas the latter approach posits that social inequality produces biological differences. The biological determinism of the old biosocial science, Roberts notes, is achieved in several ways: first, nature is separated from nurture, with allegedly inherent traits rather than imposed social structures, identified as the origins of social inequalities; second, social inequalities are claimed to be reproduced in and through the bodies of socially disadvantaged people rather than reinvented in and through unjust ideologies and institutions; third, problems that stem from social inequality are claimed to derive from the threats that oppressed people's biology itself poses to society rather than from structural barriers and state violence imposed upon oppressed people; and fourth, the old bioscience endeavors to intervene and fix perceived biological deficits in the bodies of oppressed people rather than end the structural violence that dehumanizes them and maintains an unjust social order. By contrast, the new biosocial science, Roberts explains, posits that every single biological element, every single biological process in the human body, every human cell, and everything that happens to a human cell are affected by society. In short, there is no natural body. As Roberts (2016) points out, both epigenetics and social neuroscience show that biology is not a separate entity that interacts with the environment; rather, these interactions constitute biology (see also Gilman \& Thomas, 2016; Prinz, 2012; Roberts, 1998, 2012).

Current and emerging areas of CDS crucially rely upon arguments about the social construction of biological phenomena and the cultural significance that accrues to these phenomena. In fact, the enormous attention now paid to social constructionism throughout the humanities and social sciences, as well as in some of the natural sciences, is due in large part to the compelling role that debates about social construction and essentialism have played in areas of CDS. Although philosophers of disability disagree about what disability is, as well as how, and the extent to which, disability is socially constructed, assumptions about the social construction of disability are at the heart of philosophy of disability. 
During roughly the same historical moment that contemporary mainstream political philosophers elaborated arguments about justice and disability, effectively initiating the problematization of disability in philosophy, disabled people themselves, both within and outside of the university, and at various sites across the globe, began to advance their own social constructionist claims to entitlement, articulating their own convictions about what justice for disabled people requires. In the last decades of the twentieth century, two geographically and ideologically distinct social movements coalesced, each with its own terminology to signify the conceptual objects of disability. It is from these formative grassroots social movements that the academic field of disability studies, as an interdisciplinary area of inquiry, indeed as an area of CDS, emerged.

In 1976, the Union for Physically Impaired Against Segregation (UPIAS), an activist group in the United Kingdom that understood social relations in historical materialist terms, articulated a set of principles in which they argued that the situation of disabled people is largely socially manufactured. The principles were intended to counter the medicalized understanding of disability according to which disability is a natural or biological defect that ought to be prevented, eliminated, or corrected. The motivation for the UPIAS principles was a distinction between impairment (construed as a natural human attribute) and disability (construed as a form of social disadvantage) that has become generally known as the "social model of disability" or simply "social model," but which, to avoid ambiguity (see Tremain, 2017, esp. pp. 9-11), I refer to as "the British social model of disability" ("BSM"). In the terms of the BSM, disability is the form of social disadvantage imposed upon "people with impairments" by a social system that discriminates against them and excludes them from full participation in social life. For proponents of the BSM, this form of social disadvantage (disability) is neither equal to nor a necessary consequence of people's impairments. Proponents of the BSM thus claim that their conception of disability breaks the causal link between one's embodiment and personal circumstances (impairment) and one's cultural location and social circumstances (disability). Indeed, proponents of the BSM argue that the distinction between impairment and disability that their model institutes is the single most important innovation of the contemporary "disabled people's" movement. Given that disability is not a necessary consequence of impairment, they argue, governments and policymakers should create policies and practices that mitigate the social disadvantages (such as discrimination in housing, employment, and education) that people with impairments confront rather than direct resources and goods to medical research and technology that aim to correct people with impairments themselves (Oliver, 1996).

Although historian of disability Paul Longmore (2003) traced activism by "people with disabilities" in the United States to the Great Depression in the 1930s, most disability theorists and activists locate the beginnings of the American "disability rights" movement in the early 1970s when Ed Roberts and other "students with disabilities" at the University of California at Berkeley formed a group called "The Rolling Quads" to protest their poor living conditions on the UC-Berkeley campus. When this group of students with disabilities and their allies opened the first "Independent Living Center" 
(ILC) in Berkeley, it is said, the American disability rights movement was born. Roberts and other "disability activists" in the United States, who were spurred on by the successes of the Independent Living Movement, the women's movement, and the Black civil rights movement, as well as by the ideological assumptions of liberal individualism, went on to fight long and hard for legislation that would institutionalize a tripartite conception of disability into U.S. domestic policy. On the terms of this conception, a disability is understood as a functional limitation caused by an impairment or biological deficit, a limitation in function often met with social prejudice and exclusion, which was initially referred to as "handicap," though is now referred to as "disability discrimination" (see Tremain, 2017 for an explanation for this transition). The claims to entitlement that early American disability activists advanced-understood in terms of civil rights and equal opportunitywere ultimately institutionalized in the American With Disabilities Act of 1990, which, to many activists, signaled the emergence of people with disabilities as a bona fide social minority group.

Like the activism of feminist movements internationally, global LGBTQI movements, the Black civil rights movement in the United States, and other diasporic people's movements worldwide, the activism of disabled people's movements in the United Kingdom, United States, and elsewhere has motivated disabled people and their allies to steadily take up space within the university. As I noted at the outset of this article, disability studies courses and programs are now offered in universities and colleges virtually everywhere around the world. As I have pointed out, furthermore, disability scholars and researchers can be found worldwide in many "traditional" university and college departments, including philosophy departments.

Philosophers of disability increasingly address issues pertinent to disability that nondisabled academics have either omitted from serious consideration or have misrepresented in ways that detrimentally affect disabled people. Philosophers of disability also increasingly work to identify and challenge the ableist assumptions that constitute and contribute to many of the taken-for-granted assumptions of Western European philosophy on which contemporary philosophers rely and thus continue to reproduce. That is, philosophers of disability variously concentrate on the assumptions and biases about disability that philosophical claims presuppose as well as on how disabled people have been either vilified within Euro-American, Western philosophy or exiled from it. Indeed, the approaches to disability that philosophers of disability advance, resist and run counter to the dominant conceptualization of disability that is persistently elaborated within bioethics, cognitive science, and mainstream political philosophy and ethics especially, according to which disability is a natural deficit, personal misfortune, or pathology that necessarily reduces the quality and worth of disabled people's lives and inevitably leads to the social and economic disadvantages that disabled people confront. Insofar as practitioners of the Euro-American philosophical tradition have, with few exceptions, cast disability as a natural, negative, and inert state of affairs in this way, they have largely removed disability from the realm of philosophical inquiry and kept at bay philosophical debate and questioning about its epistemological, ethical, and political status. By contrast, philosophers of disability both use and take a critical stance 
toward the history of philosophy and the contemporary practice of mainstream philosophy to variously elaborate new ways in which to think about disability and about the current social, political, cultural, and economic position of disabled people. They do so by employing the very methods, concepts, analytical rigor, and argumentative tools of the Euro-American, Western philosophical tradition and the discipline of philosophy in which they were trained.

\section{Feminist Influences in Philosophy of Disability}

Many philosophers of disability are also feminist philosophers. Like philosophers of disability, feminist philosophers take a critical approach to the methodologies, values, and concerns of traditional areas of philosophy. They question the assumptions and biases upon which these established areas of philosophy rely, identifying how these assumptions and biases reinforce forms of social subordination, especially with respect to gender. In stark contrast to the disinterested and disembedded approach that mainstream philosophers advocate, feminist epistemologists and feminist philosophers of science have argued that philosophical inquiry must take account of information about the social contexts from which both philosophical questions emerge and responses to them are generated, including the subjectivity and social positioning of any given questioner and respondent. For example, Sandra Harding, among others, has argued that information about the subjectivity and social situation of knowers can provide valuable insights into the assumptions and biases on which a given position relies (see Harding, 1986, 1991, 2015). To advance this claim, Harding and other feminist philosophers assume some version of "standpoint epistemology."

Feminist standpoint epistemologies variously postulate that people in subordinated social positions have, by virtue of their subordinated social status, understandings of social relations that are superior to-that is, more complete and objective than-the understandings of these relations that members of privileged social groups have (see Dotson, 2011, 2012; Harding, 1986, 2015; Hartsock, 1983). Alison Wylie points out that standpoint theory is an explicitly political social epistemology whose "central and motivating insight is an inversion thesis" (Wylie, 2003, p. 26). As Wylie explains it, standpoint theory holds that people who are subjected to systemic forms of domination may be epistemically privileged, that is, may, by virtue of their experiences, have access to different or better kinds of knowledge than people who are comparatively privileged. Feminist standpoint theorists, Wylie notes, "argue that gender is one dimension of social differentiation that may make a difference epistemically." The aim of feminist standpoint theorists, she writes, "is to both understand how the systematic partiality of authoritative knowledge arises-specifically, its androcentrism and sexism - and to account for the constructive contributions made by those working from marginal standpoints (especially feminist standpoints) in countering this partiality" (Wylie, 2003, p. 26).

Feminist philosophical insights about situated knowledges have influenced feminist philosophers who work on disability, especially given the commitment of feminist standpoint theorists who-however much they otherwise disagree-concur that standpoint theories must not "presuppose an essentialist definition of the social categories or 
collectivities in terms of which epistemically relevant standpoints are characterized" (Wylie, 2003, p. 26; emphasis in Wylie). Indeed, philosophers of disability who incorporate feminist insights into their philosophy of disability critically evaluate the arguments of other philosophers and theorists of disability through the concepts, political commitments, critical insights, and personal investments that shape feminist, anti-ableist, antiracist, classconscious, and antiheterosexist theory and practice.

My feminist philosophy of disability shares many features with other feminist philosophies of disability, some of which features distinguish varieties of feminist philosophy of disability from work done elsewhere in the broad, interdisciplinary field of feminist disability studies. Nevertheless, the feminist philosophy of disability that I hold relies upon an understanding of disability that distinguishes it from other feminist philosophies of disability, in addition to distinguishing it from other theories in feminist disability studies. Other feminist philosophies and theories of disability uncritically retain some of the unsavory elements of dominant theoretical approaches to disability insofar as they variously conceive disability as (1) the functional manifestation of an intrinsic characteristic, a biological difference, or a property (attribute) — for example, an impairment — that certain people embody or possess and that gives rise to certain forms of social discrimination against them; (2) the form of discrimination and oppression imposed upon people who have an intrinsic characteristic, attribute, or property construed as a human difference; or (3) some hybrid of (1) and (2) in which the relation between disability (as a functional limitation or form of social oppression) and, say, impairment (as an intrinsic characteristic, a property, or a difference that some people embody or possess) may not be clearly defined or may fluctuate from one context to another context, though, terminologically speaking, emphasis is placed upon the former (that is, disability). Although these apparently distinct conceptions of disability diverge from each other in some important ways, they depend upon roughly the same assumptions about the epistemological and ontological status of impairment and disability, as well as upon the same assumptions about social power, including the assumption according to which power is fundamentally repressive and external to preexisting objects upon which it acts. I disagree with all these assumptions (see Tremain, 2017).

\section{Foucault and Philosophy of Disability}

Following Foucault, I assume that social power is productive of the objects on which it acts and is diffused throughout society and culture rather than first and foremost repressive and centralized, as these other feminist conceptions of disability assume. In other words, my disagreement with these other conceptions of disability stems from the assumptions about causation that they make and the epistemological and ontological status that they implicitly confer upon the categories of impairment and disability. Whereas other feminist philosophers of disability variously conceive of disability as the functional outcome of a natural human characteristic, a human variation or difference, an identity, or a form of oppression in relation to which impairment is assumed to be the anterior, or prediscursive, foundation, as I have indicated, I regard disability as what Foucault referred to as an "apparatus" (dispositif) of relatively recent force relations. Impairment, I maintain, 
is an element of this apparatus produced as its naturalized and naturalizing foundation, that is, impairment is both an effect of and a mechanism of the apparatus of disability. In "The Confession of the Flesh," Foucault (1980, p. 194) defined an apparatus (dispositif) as a thoroughly heterogeneous and interconnected ensemble of discourses, institutions, architectural forms, regulatory decisions, laws, scientific statements, administrative measures, and philosophical, moral, and philanthropic propositions that responds to an "urgent need" in a certain historical moment. In other words, an apparatus is a historically specific and dispersed system of power that produces and configures practices toward certain strategic and political ends.

Many philosophers of disability, some of whom identify as "analytic" philosophers, dispute my claims about the social construction of impairment, especially my claim that impairment is as socially constructed as disability, is the naturalized foundation of (the apparatus of) disability. Some philosophers of disability who dispute this claim-that is, my claim according to which impairment is as artifactual as disability-think that the claim is unrealistic. They think that it is extreme. They dismiss the idea that impairment is a social artifact by arguing that impairments must be real (as in ontologically fundamental) things because some impairments are "really" bad or "in reality" bad and would continue to be (really) bad even if all social discrimination and systemic oppression against disabled people were eliminated. They claim that my argument about the social construction of impairment denies material reality, corporeality, and the body. Some of them point out, furthermore, that insofar as my claim about the social construction of impairment denies the material body, my view is susceptible to the same sort of charge that some feminist philosophers have directed at Foucault, namely, that (his) arguments about the historical constitution and specificity of the body deny the existence of the prediscursive, material body with which women have traditionally been associated and hence perpetuate an element of women's subordination and disenfranchisement.

In another context, I labor to address criticisms about Foucault's alleged denial of the material body; in this context therefore, I shall exclusively address the argument according to which the (allegedly) inherent badness of impairment undermines claims about its social construction (Tremain, 2017). I maintain that claims according to which impairments are bad are like claims according to which criminals are bad: both the category of impairment and the category of criminal are entirely made up and ideas about their respective badness are part of, indeed, fundamental to, how they are respectively made up, part of their construction, a necessary part of their respective designations as the things that they are. In short, there can be no politically neutral or value neutral definition or description of impairments just as there can be no politically neutral or value neutral definition or description of criminals.

Many philosophers (and theorists) of disability do not grasp the social construction of impairment because they misunderstand how modern power operates. Indeed, many philosophers (and theorists) of disability, including some feminist philosophers of disability, seem to forget that claims about the social construction of this or that are claims about how power operates with respect to this or that, how it does its work. Although philosophers of disability (and others) who argue against my claims about the social construction of 
impairment seem to assume that I disagree with them about what can be socially constructed, I actually disagree with them about how social construction takes place (as well as what is constructed). Most philosophers of disability presuppose what Foucault called a juridical or juridico-discursive conception of power according to which power is fundamentally repressive, subtracts liberties, withholds rights, and so on. Many of them believe, furthermore, that there are (fundamental) entities—-such as sexes, impairments, chemicals, values, and so on-that exist prior to social practices, entities from which, out of which, and through which social construction of derivative entities takes place. As I have noted, with Foucault, I contend, to the contrary, that power is primarily productive rather than (merely) repressive: it produces objects, discourses, bodies, candidates for true-or-false, values, and ontologies, and it constructs identities, relations, practices, and so on. I submit, therefore, that until and unless philosophers of disability who criticize my claim(s) about the social construction of impairment come to recognize that the crux of our disagreement about the social construction of impairment is a disagreement about how power operates, a disagreement about whether power is primarily prohibitive or constitutive, a disagreement about whether power operates most effectively through repression or through productive constraints, they will not understand the claims nor understand how (the apparatus of) disability operates and thus the effects of their work, including their criticisms of my work in this regard, will themselves be limited and constrained, as well as (out)dated.

My use of Foucault's idea of apparatus enables me to move philosophical discussion about disability away from restrictive conceptualizations of it as (for instance) a personal characteristic or attribute, a property of given individuals, an identity, a difference, or a form of social oppression. In addition, my assumption that disability is an apparatus, in Foucault's sense, moves philosophical discussion of disability toward a more comprehensive conceptualization of it than other conceptions of disability provide: a conceptualization of disability that is (among other things) historicist and relativist and, hence, culturally sensitive in ways that other conceptions of it are not. As an apparatus, disability is a historically specific aggregate that comprises, constitutes, and is constituted by and through a complex and complicated set of discourses, technologies, identities, and practices that emerge from medical and scientific research, government policies and administrative decisions, academic initiatives, activism, art and literature, mainstream popular culture, and so on. Although some of the diverse elements of the apparatus of disability seem to have different and even conflicting aims, design strategies, and techniques of application, the elements of the apparatus are nevertheless co-constitutive and mutually reinforcing.

To understand disability as an apparatus is to conceive of it as a far-reaching and systemic matrix of power that contributes to, is inseparable from, and reinforces other apparatuses of historical force relations, including the apparatuses of race, gender, class, nationality, age, and sexuality. With this understanding, disability is not a metaphysical substrate, a natural, biological category, or a characteristic that only certain individuals embody or possess but is rather a historically contingent network of force relations in which everyone is implicated and entangled and in relation to which everyone occupies a 
position. My argument is that the conception of disability as an apparatus, were it taken up by philosophers of disability and advanced through CDS and philosophy itself, has the potential to (1) radically change the way that philosophers and other academics think about disability and disabled people and, ultimately, change philosophy and the university themselves; (2) significantly transform the way that disabled people understand themselves and their social and political situation; and (3) substantially reconfigure the current social, political, and economic relations of power that operate to marginalize and disenfranchise disabled people.

\section{REFERENCES}

Dotson, K. (2011). Tracking epistemic violence, tracking practices of silencing. Hypatia: A Journal of Feminist Philosophy, 26, 236-257.

Dotson, K. (2012). A cautionary tale: On limiting epistemic oppression. Frontiers, 33, 24-47.

Dworkin, R. (1981a). What is equality? Part 1: Equality of welfare. Philosophy and Public Affairs, 10, $185-246$.

Dworkin, R. (1981b). What is equality? Part 2: Equality of resources. Philosophy and Public Affairs, 10, 283-345.

Foucault, M. (1980). The confession of the flesh. In C. Gordon (Ed.), Power/knowledge: Selected interviews and other writings, 1972-1977 (pp. 194-228). New York, NY: Pantheon Books.

Foucault, M. (2003). Polemics and problematizations: An interview with Michel Foucault. In P. Rabinow \& N. Rose (Eds.), The essential Foucault: Selections from essential works of Foucault, 1954-1984 (pp. 10-24). New York, NY: The New Press.

Gilman, S. L., \& Thomas, J. M. (2016). Are racists crazy? How prejudice, racism, and antisemitism became markers of insanity. New York: New York University Press.

Harding, S. (1986). The science question in feminism. Ithaca, NY: Cornell University Press.

Harding, S. (1991). Whose science? Whose knowledge? Thinking from women's lives. Ithaca, NY: Cornell University Press.

Harding, S. (2015). Objectivity and diversity: Another logic of scientific research. Ithaca, NY: Cornell University Press.

Hartsock, N. C. M. (1983). The feminist standpoint: Developing the ground for a specifically feminist historical materialism. In S. Harding \& M. Hintikka (Eds.), Discovering reality (pp. 283-310). Dordrecht, The Netherlands: D. Reidel.

Longmore, P. (2003). Why I burned my book and other essays on disability. Philadelphia, PA: Temple University Press.

Mills, C. W. (2005). "Ideal theory" as ideology. Hypatia: A Journal of Feminist Philosophy, 20, 166-184.

Oliver, M. (1996). Understanding disability: From theory to practice. London: Macmillan.

Prinz, J. J. (2012). Beyond human nature: How culture and experience shape the human mind. New York, NY: W.W. Norton.

Rawls, J. (1971). A theory of justice. Cambridge, MA: Belknap Press of Harvard University Press.

Roberts, D. E. (1998). Killing the Black body: Race, reproduction, and the meaning of liberty. New York, NY: Vintage Books.

Roberts, D. E. (2012). Fatal invention: How science, politics, and big business re-create race in the twenty-first century. New York, NY: The New Press.

Roberts, D. E. (2016, November 2). The ethics of the biosocial: The old biosocial and the legacy of unethical science. Tanner Lectures on Human Values, Mahindra Humanities Center, Harvard University, Cambridge, MA.

Sen, A. (1979, May). Equality of what? The Tanner Lectures on Human Values, Delivered at Stanford University. 
Shelby, T. (2007). We who are dark: The philosophical foundations of Black solidarity. Cambridge, MA: Harvard University Press.

Tremain, S. (1996). Dworkin on disablement and resources. The Canadian Journal of Law and Jurisprudence: An International Journal of Legal Thought, 9, 343-359.

Tremain, S. (2010). Biopower, styles of reasoning, and what's still missing from the stem cell debates. Hypatia: A Journal of Feminist Philosophy, 25, 577-609.

Tremain, S. (2013). Introducing feminist philosophy of disability. Disability Studies Quarterly, 33(4). Retrieved from http://dsq-sds.org/article/view/3877/3402

Tremain, S. (2014). Disabling philosophy. The Philosophers' Magazine, 65, 15-17.

Tremain, S. L. (2017). Foucault and feminist philosophy of disability. Ann Arbor: University of Michigan Press.

Wylie, A. (2003). Why standpoint matters. In R. Figueroa \& S. Harding (Eds.), Science and other cultures: Issues in philosophies of science and technology (pp. 26-46). New York, NY: Routledge. 